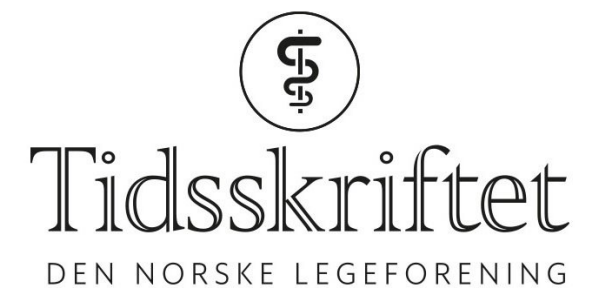

DEN NORSKE LEGEFORENING

\title{
Psykotisk, fengslet og alene
}

LEDER

\section{RANDI ROSENQVIST}

E-post: randi@rosenqvist.no

Randi Rosenqvist er spesialist i psykiatri og seniorrådgiver ved Ila fengsel og forvaringsanstalt, og overlege ved Kompetansesenter for sikkerhetspsykiatri, fengselspsykiatri og rettspsykiatri, Oslo Universitetssykehus.

Forfatter har fylt ut ICMJE-skjemaet og oppgir følgende interessekonflikter: Hun er ansatt i Kriminalomsorgen.

Plassproblemer i sikkerhetspsykiatrien fører til at psykotiske innsatte holdes isolert på cellen.

Ansatte i kriminalomsorgen har mange ganger påpekt at svært syke innsatte ikke får tilstrekkelig oppfølging fra psykisk helsevern. Dette ble igjen aktualisert våren 2018, blant annet gjennom Brennpunkt-dokumentaren «Fengslet og forlatt» på NRK, reportasjer i Bergens Tidende og en kronikk fra Sivilombudsmannen $(1,2,3)$.

Psykotiske pasienter skal ikke sitte i fengsel, men det gjør de. Omkring $4 \%$ av soningsfanger og en noe større andel varetektsfanger har en pågående psykose (4). I tillegg kommer en gruppe innsatte som ikke har en psykoselidelse, men som har en funksjonssvikt som tilsier at de er alvorlig sinnslidende (5) og således, når de også er til fare for andre, kunne vært tvangsinnlagt i en psykiatrisk avdeling.

Fengselsinnsatte som er urolige og truende, kan ikke være på ordinære fengselsavdelinger, der det ofte er 12-14 innsatte og kanskje 1-2 ansatte til stede. Psykotiske innsatte som utgjør en sikkerhetsrisiko, hører hjemme i en psykiatrisk sikkerhetsavdeling. Dessverre er antallet plasser ved slike avdelinger blitt redusert med nesten $20 \% \mathrm{i}$ forhold til folketallet de siste ti årene. I 2015 var det 4,1 døgnplasser per 100 ooo innbyggere i norske sikkerhetsavdelinger, mot 8 plasser per 100 ooo i Sverige og 6,6 i Danmark (6).

Fordi innsatte som utgjør en sikkerhetsrisiko ofte må vente lenge på plass i psykiatrisk sikkerhetsavdeling, blir de i stedet «eneromsplassert», noe som i realiteten er å bli innelåst alene på en celle med seng, bord og stol. De innsatte kan gjerne få med seg et par bøker, men cellen kan ikke ha gjenstander som kan brukes til å skade seg selv eller andre. Ifølge straffegjennomføringsloven $\S 37$ kan slik eneromsplassering vare i opptil ett år. Det er anført at innsatte «flere ganger daglig [skal] tilsees av tilsatte». Hadde de vært innlagt i psykisk helsevern, hadde slik isolasjon vært lovstridig. Det er åpenbart galt å behandle psykotiske og andre alvorlig sinnslidende slik. Symptomtrykket blir høyere når de knapt får bekreftelse fra andre mennesker, og atferden blir naturlig nok også dårligere.

Praksisen er kritikkverdig, men dersom den innsatte utgjør en sikkerhetsrisiko, er det ikke andre muligheter innen dagens organisering. Noen innsatte blir tatt imot som øyeblikkelig hjelp i akuttavdelinger. Dessverre blir de, som mange andre pasienter, raskt skrevet ut til 
poliklinisk oppfølging. Helsetjenester til innsatte drives etter «importmodellen». En innsatt som oppfattes som alvorlig sinnslidende, må henvises til det lokale distriktspsykiatriske senter (DPS) for vurdering. Der vurderer man om det er behov for innleggelse. Prosessen er lang, og enda lengre dersom den innsatte er negativ til psykiatrisk intervensjon. Jeg har inntrykk av at terskelen for å bli henvist til allerede fulle sikkerhetsavdelinger er høy. Det er forståelig-dersom det nesten ikke er plasser i sikkerhetspsykiatrien, så må man prioritere pasienter som ikke allerede er i annen institusjon. Fengselsleder kan klage på manglende helseoppfølging når pasienten ikke selv kan gjøre det. Men nå som det ikke lenger er obligatorisk med innleggelsesbegjærer (tutor) ved tvangsinnleggelser, skjer søknader ofte uten fengselsleders medvirkning, og helsevesenet er ikke alltid villig til å meddele hvorfor en antatt pasient får avslag på behandling. Det er bekymringsfullt dersom kriminalomsorgen som er ansvarlig for totalomsorgen for en innsatt, ikke får vite hvilke helseutfordringer vedkommende har. Disse sykeste innsatte er ikke alltid i stand til å samarbeide, men helsevesenet ivaretar taushetsplikten også i tilfeller der den innsatte kanskje ikke burde blitt vurdert som samtykkekompetent.

Kriminalomsorgen sentralt bør ikke ignorere disse innsattes behov. Alle store fengsler har innsatte som trenger tettere oppfølging enn det som ligger i den vanlige fengselsdriften, og det er disse som gjerne blir «eneromsplassert». Ved Ila fengsel og forvaringsanstalt har vi siden 2014 hatt ekstra bemanning for å «lufte» innsatte som er langtidsisolert og som trenger samvær med andre mennesker. Flere fengsler burde få ekstrabemanning for at de sykeste innsatte også kan få være med på aktiviteter. De regionale psykiatriske sikkerhetsavdelingene i Trondheim og Oslo har begge planer om nybygg med noe $ø$ ket kapasitet. Men foreløpig er det ikke stukket noen spade i jorden. Situasjonen med plassproblemer i psykiatrien og syke innsatte i fengsler vil dermed vare i minst fem år til.

I påvente av at sikkerhetspsykiatrien får større kapasitet, er det viktig å få innlagte pasienter videreført til lukkede langtidsavdelinger eller til omsorg i kommunene dersom dette kan gjøres betryggende. Det er ikke usannsynlig at plassproblemene i sikkerhetspsykiatrien kan bedres noe dersom spesialisthelsetjenesten og kommunene har mulighet til en bedre omsorg på lavere nivå. Helsedirektoratet har nå initiert en undersøkelse om hvilke pasienter som utgjør "propper» i sikkerhetspsykiatrien og som bør videreføres. Selv har jeg tatt til orde for at det etableres «sikkerhetshjem» for spesielt dårlig fungerende pasienter som over lang tid vil utgjøre en fare for samfunnet, men som ikke har et ytterligere behandlingspotensiale og som derfor «bor» i psykiatriske sikkerhetsavdelinger eller i fengsel som forvaringsdømte. Våre politikere må forholde seg til at noen kommer til å være i denne kategorien livet ut, og at disse også må få et anstendig tilbud.

\section{LITTERATUR:}

1. Brennpunkt. Episode: Fengslet og forlatt. NRK TV 18.4.2018.

https://tv.nrk.no/serie/brennpunkt/MDDP11000518/18-04-2018(27.8.2018).

2. Fredriksen I, Aarøy TA, Eriksen AG et al. Fortvilelsen på celle 6143. Bergens Tidende (nettutgaven). https://www.bt.no/btmagasinet/i/VR1dy3/Fortvilelsen-pa-celle-6143 (27.8.2018).

3. Falkanger TA. Isolasjon av psykisk syke innsatte er uverdig. Sivilombudsmannen. https://www.sivilombudsmannen.no/aktuelt/isolasjon-av-psykisk-syke-innsatte-er-uverdig/(27.8.2018).

4. Cramer V. The prevalence of mental disorders among convicted inmates in Norwegian prisons. Oslo: Oslo universitetssykehus, 2016.

http://sifer.no/files/Hel_oppdatert_Victoria_Cramer_rapport_engelsk.pdf(27.8.2018).

5. Psykisk helsevernloven og psykisk helsevernforskriften med kommentarer. Rundskriv. Oslo: Helsedirektoratet, 2017.

https://helsedirektoratet.no/Retningslinjer/Psykisk\%2ohelsevernloven\%2oog\%2opsykisk\%2ohelsevernf orskriften\%2omed\%2okommentarer.pdf(27.8.2018).

6. Sikkerhetspsykiatrien i Norge i. 2015. En statusundersøkelse. Oslo: Oslo Universitetssykehus, 2015. 
http://sifer.no/files/RIKTIG_versjon_Statusrapport_Sikkerhetspsykiatri_-_2015.pdf(27.8.2018).

Publisert: 27. september 2018. Tidsskr Nor Legeforen. DOI:10.4045/tidsskr.18.0529

(C) Tidsskrift for Den norske legeforening 2020. Lastet ned fra tidsskriftet.no 